Check for updates

\section{London}

Cite this as: $B M J 2020 ; 371: \mathrm{m} 4832$ http://dx.doi.org/10.1136/bmj.m4832 Published: 14 December 2020

\title{
Covid-19: Avoid indoor mixing over Christmas or risk third wave, warns iSAGE
}

Adrian O'Dowd

The government must rethink its plans for easing covid-19 restrictions over Christmas and be far more explicit as to what the public should and should not do, to prevent a large spike in cases in the new year, experts have urged.

The Independent Scientific Advisory Group for Emergencies, which provides independent scientific advice to the government and the public, has called for a rethink in the light of surging rates of infection in parts of the United Kingdom. ${ }^{1}$

The group said that the UK's policy ${ }^{2}$ to allow up to three households to meet indoors between 23 and 27 December brought with it the risk of infection transmission. Given the stalling decrease in infection rates nationally and a surge of infections in some areas (notably the south-east of England), if a large proportion of the population took advantage of the three household rule then there was a "very real danger of a third wave of the pandemic," the experts warned.

At a press briefing held on 11 December Independent SAGE called for the public to consider meeting outdoors rather than indoors, if possible, and for the government to support this through a fund for outdoor community events. There could also be a "pandemic fuel allowance" so that people could keep their homes ventilated while at the same time turning up the heating to keep warm.

The experts said the government had to provide more detailed guidance about how people should handle meeting in the five days over Christmas during which restrictions were being eased.

Stephen Reicher, professor of psychology at the University of St Andrews and a member of iSAGE, said, "The government has said three households can mix, but 'can' does not mean 'should.'

"We are at high levels of infection throughout the country. From that base, if we mix, and if everybody takes advantage of three households mixing, then there is no doubt that the infection rate will spike and we will live to regret it in the new year. Not only will people die, but it will also overwhelm the NHS at a time when we are trying to roll out the vaccine.

"The safest thing, by far, is not to mix. If people decide to meet, then there needs to be clear guidance on keeping safe and clear support.”

Fellow group member Kit Yates, co-director of the Centre for Mathematical Biology at the University of Bath, added, "What we need to be doing is reiterating what the rules are but also try to give people opportunities to know what the best way to meet up safely is.”
Members of the public should welcome the vaccines being offered to them to fight the coronavirus, said Danny Altman, professor of immunology at Imperial College London.

"We've got some great, really effective vaccines out there, and my big statement is that you should grab any one they offer you and run with it, because the only way that I know to get out of this mess is to have a high level in your serum of neutralising antibodies that block the entry of that virus into the cell and keep them high," he said.

Independent Scientific Advisory Group for Emergencies. Rethinking Christmas: A three point plan to keep families and communities safe. 11 Dec 2020. https://www.independentsage.org/wp-content/uploads/2020/12/Christmas-3-point-plan-final.pdf.

2 Cabinet Office. Guidance: Making a Christmas bubble with friends and family. 3 Dec 2020. https://www.gov.uk/government/publications/making a-christmas-bubble-with-friends-and-family/making-a-christmas-bubblewith-friends-and-family\#if-you-are-clinically-extremely-vulnerable.

This article is made freely available for use in accordance with BMJ's website terms and conditions for the duration of the covid-19 pandemic or until otherwise determined by BMJ. You may use, download and print the article for any lawful, non-commercial purpose (including text and data mining) provided that all copyright notices and trade marks are retained. 